\title{
Fatty acids and nutrients in the flour made from tilapia (Oreochromis niloticus) heads
}

\author{
Ácidos graxos e nutrientes em farinha de cabeças de tilápia (Oreochromis niloticus) \\ Flávia Braidotti STEVANATO ${ }^{1}$, Vanessa Vivian ALMEIDA ${ }^{1}$, Makoto MATSUSHITA ${ }^{1}$, \\ Cláudio Celestino OLIVEIRA ${ }^{1}$, Nilson Evelázio SOUZA ${ }^{1}$, Jesuí Vergilio VISENTAINER ${ }^{1 *}$
}

\begin{abstract}
The objective of this work was to analyze the fatty acid composition and nutrient potential of flour made from tilapia heads, which are normally discarded during the filleting operation. Significant differences were found between the proximate composition (moisture, ash, protein and total lipids) of the in natura tilapia and the flour, due to the drying process. The predominant fatty acids in the heads (in natura and in the flour) were palmitic acid (1,999 mg.100 g-1 and 7,699 mg.100 g $\mathrm{g}^{-1}$, respectively), oleic acid (3,128 mg.100 g and $11,447 \mathrm{mg} .100 \mathrm{~g}{ }^{-1}$, respectively), and linoleic acid (1,018 mg.100 g and 3,784 mg.100 g $\mathrm{g}^{-1}$, respectively). The results lead us to conclude that tilapia head flour offers high levels of protein (38.41\%), total lipids (35.46\%), and ash (minerals) (19.38\%). The content of omega-3 (731 mg.100 $\left.\mathrm{g}^{-1}\right)$ were proved to be satisfactory. Also, n-6/n-3 ratio was 6.15 and PUFA/SFA ratio was 0.47 , which are in agreement with the recommended levels. Thus, tilapia heads can be used as a low-cost raw material for food fit for human consumption.
\end{abstract}

Keywords: tilapia; heads; flour; fatty acids; nutrients.

\section{Resumo}

O objetivo deste trabalho foi avaliar a composição em ácidos graxos e o potencial em nutrientes em cabeças de tilápias in natura processadas na forma de farinha. As cabeças de tilápia normalmente são resíduos não aproveitados e descartados na operação de filetagem pelas indústrias e pesqueiros. Diferenças significativas foram encontradas na composição centesimal (umidade, cinza, proteína e lipídios totais) entre as cabeças de tilápia in natura e a farinha, provavelmente devido ao processo de secagem. Os ácidos graxos predominantes nas cabeças (in natura e na farinha) foram os ácidos: palmítico (1.999 mg.100 g-1 e $7.699 \mathrm{mg} .100 \mathrm{~g}^{-1}$, respectivamente), oléico $\left(3.128 \mathrm{mg} .100 \mathrm{~g}^{-1}\right.$ e $11.447 \mathrm{mg} .100 \mathrm{~g}{ }^{-1}$, respectivamente) e linoléico (1.018 mg. $100 \mathrm{~g}^{-1}$ e $3.784 \mathrm{mg} .100 \mathrm{~g}^{-1}$, respectivamente). Os resultados da farinha da cabeça apresentaram elevados teores de proteína $(38,41 \%)$, de lipídios totais $(35,46 \%)$ e de cinza (19,38\%). A concentração de ácidos ômega-3 (731 mg.100 g $\left.{ }^{-1}\right)$ indica que a farinha é uma boa fonte destes ácidos e as razões n-6/n-3 de 6,15 e AGPI/AGS de 0,47 estão de acordo com os níveis recomendados para uma alimentação saudável. Desta forma, as cabeças de tilápia podem ser utilizadas como um alimento nutritivo e de baixo custo para o consumo humano.

Palavras-chave: tilápia; cabeças; farinha; ácidos graxos; nutrientes.

\section{Introduction}

The Nile tilapia (Orechromis niloticus) is one of the most cultivated fresh-water fish in Brazil and worldwide (JORY; ALCESTE; CABRERA, 2000). From the capture to the end processing of this fish, approximately $28 \%$ of the total catch is wasted. Sometimes the waste is used to produce processed animal feed, but most often it is discarded, contributing to increase environmental pollution (FAO, 2000). By fish waste, we mean small or dark-meat fish, fatty tissue, and parts such as the head, scales, spinal column, skeleton, liver, skin and viscera (OETTERER, 2003).

It should be considered that fish tissue presents high nutritional value and therefore is a particularly recommended dietary component (ZMIJEWSKI et al., 2006). Protein from fish tissue is characterized by a desirable amino acid composition. The tissue is also rich in vitamins $\mathrm{A}, \mathrm{D}$ and the $\mathrm{B}$ group. In addition, fish are a good source of micro and macro-elements such as calcium, phosphorus, selenium and manganese
(KOLAKOWSKA; KOLAKOWSKI, 2000). Muscle (JUSTI et al., 2003; VISENTAINER et al., 2005) and waste of fish, such as the head (MOREIRA et al., 2003), are the main source of verylong-chain (number of carbons $\geq 20$ ) polyunsaturated fatty acids (n-3 VLC-PUFAs), which have beneficial and even therapeutic effects on human health (ACKMAN, 2000; GARCIA, 1998; KOLANOWSKI; SWIDERSKI; BERGER, 1999). Eicosapentaenoic (EPA, 20:5n-6) and docosahexaenoic (DHA, 22:6n-3) fatty acids have been the subject of innumerable studies in the past few decades, being important for their various benefits to human health, including lowering the risk of cardiovascular diseases (DYEBERG; BANG, 1979; FIRBANK et al., 2002; PENNY et al., 2002), anti-inflammatory and antithrombotic effects (SIMOPOULOS, 2002), reduction of blood cholesterol levels and cancer prevention (LEE; LIP, 2003).

Recommendations for the inclusion of n-3 fatty acids in the human diet in relation to $n-6$ fatty acids have been made 
in several countries and currently the suggested n-6/n-3 ratio values range from 2 to 5.1 (CHARDIGNY; BRETILLON; SEBÉDIO, 2001; SCHAEFER, 2002; SIMOPOULOS; LEAF; SALEM, 1999).

In many countries of the world, the huge quantities of fish waste produced are often discarded into the environment and become a source of pollution. In literature, there are practically no studies on fish waste products and they are very seldom utilized for food. With these facts in mind, the aim of the present work is to evaluate the fatty acid composition and nutrient potential of tilapia heads, in natura and after processing in the form of flour, with the ultimate goal of its consumption by humans.

\section{Materials and methods}

\subsection{Sampling}

The tilapia heads ( 35 heads) were washed with filtered water, cleaned (dried) with paper towels and steam-cooked (pans on the stove) for 25 minutes. After cooking, the heads were ground in an endless-screw grinder, placed on trays and dried in an oven for 4 hours at $180^{\circ} \mathrm{C}$. Next, the flour was sieved using a 14-mesh stainless steel sieve. The steps shown in the flowchart in Figure 1 were followed for THF (Tilapia Head Flour) processing.

\subsection{Analytical methods}

Moisture and ash contents were determined gravimetrically by desiccation of the samples at $105^{\circ} \mathrm{C}$ and by incineration in an oven at $600{ }^{\circ} \mathrm{C}$, respectively. Crude protein was obtained by the Kjeldahl method (CUNNIFF, 1998), and total lipids were extracted from muscle tissue using the Bligh and Dyer method (BLIGH; DYER, 1959). Three replicates were used in all chemi$\mathrm{cal}$ analyses.

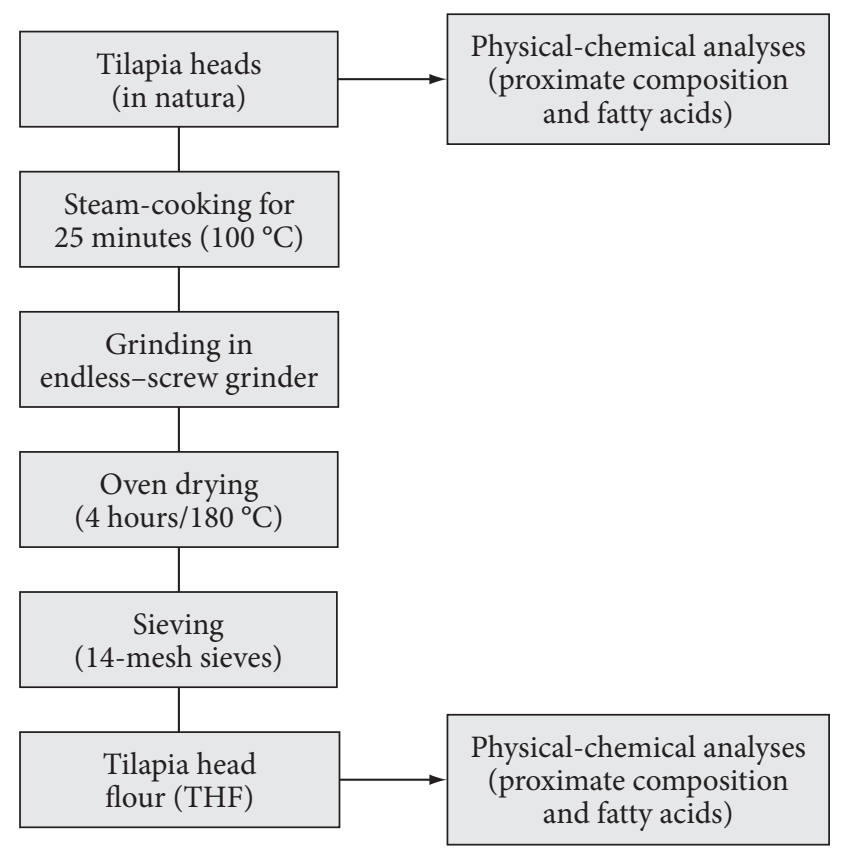

Figure 1. Flowchart for tilapia head flour (THF) production.
Fatty acid methyl esters (FAME) were prepared by methylation of the total lipids (TL), as described by Joseph and Ackman (1992). Fatty acid esters were separated in a gas chromatograph 14-A (Shimadzu, Japan) equipped with a fused silica capillary column CP-cyanopropyl (Select fame Varian - CP 7420) $(100 \mathrm{~m} \times 0.25 \mathrm{~mm}$ i.d. $\times 0.25 \mu \mathrm{m}$ film) and flame ionization detector. The operation parameters were as follows: detector temperature, $240^{\circ} \mathrm{C}$; injection port temperature, $220^{\circ} \mathrm{C}$; column temperature, $165^{\circ} \mathrm{C}$ for 18 minutes, programmed to increase at $4{ }^{\circ} \mathrm{C} / \mathrm{min}$ to $235^{\circ} \mathrm{C}$, with a final holding time of 24 minutes. The gas flow rates used were $1.0 \mathrm{~mL} / \mathrm{min}$, carrier gas $\left(\mathrm{H}_{2}\right)$, $30 \mathrm{~mL} / \mathrm{min}$ make-up gas $\left(\mathrm{N}_{2}\right)$, and 30 and $300 \mathrm{~mL} / \mathrm{min}$ flame gases $\left(\mathrm{H}_{2}\right.$ and synthetic air, respectively). The sample splitting rate was 1:50 and samples $(1 \mu \mathrm{L})$ were injected in triplicate. Peak areas were determined by Varian Star acquisition program. For the identification of the fatty acids, their retention times were compared to those of standard methyl esters (Sigma, St. Louis, MO, USA). Equivalent chain-length values (ECL) were used, according to Stransky, Jursik and Vitek (1997) and Thompson (1996). Data were calculated using the normalized peak area percentages of total fatty acid content and converted into mg. $100 \mathrm{~g}^{-1}$ lipids using a conversion factor for fish according to Weihrauch et al. (1977).

\subsection{Statistical analysis}

The results were submitted to analysis of variance (ANOVA) and the Tukey test (5\% probability) using the Statistica 5.0 software (STATSOFT, 1995).

\section{Results and discussion}

The average mass of ground in natura tilapia heads (total of 35 heads) was $5.54 \mathrm{~kg}$. After cooking, grinding, drying and sieving, $1.99 \mathrm{~kg}$ were obtained, which corresponds to $35.9 \%$ of the initial mass and $10.8 \%$ in relation to the whole fish.

Analyzing the proximate composition (moisture, crude protein, ash and total lipids) of the in natura tilapia heads and of tilapia head flour (Table 1), it was possible to observe that there are statistically significant differences $(p<0.05)$ between the levels of moisture, crude protein, ash and total lipids, as the concentrations of the three latter increased due to the water removal during the drying process and due to the sieving process that preferentially retained material rich in protein. The amount of moisture found in in natura tilapia heads was $67.24 \%$ (Table 1) and decreased to $6.01 \%$ in the tilapia head flour. These values are in accordance to the Riispoa (1997), which requires whole dried fish moisture content to be lower than $12 \%$.

Table 1. Proximate composition of in natura tilapia heads and tilapia head flour (THF).

\begin{tabular}{|c|c|c|c|c|}
\hline Constituents & $\begin{array}{c}\text { Moisture } \\
(\%)\end{array}$ & $\begin{array}{l}\text { Crude } \\
\text { protein b } \\
\quad(\%)\end{array}$ & $\begin{array}{l}\text { Ash } \\
(\%)\end{array}$ & $\begin{array}{c}\text { Total lipids } \\
(\%)\end{array}$ \\
\hline In natura & $67.24 \pm 0.20^{\mathrm{a}}$ & $16.48 \pm 0.15^{a}$ & $5.72 \pm 0.04^{\mathrm{a}}$ & $9.56 \pm 0.39^{a}$ \\
\hline Flour & $6.01 \pm 0.09^{\mathrm{b}}$ & $38.41 \pm 0.12^{\mathrm{b}}$ & $19.38 \pm 0.14^{\mathrm{b}}$ & $35.46 \pm 0.16^{\mathrm{b}}$ \\
\hline \multicolumn{5}{|c|}{$\begin{array}{l}\text { ach value is the average of five samples analyzed in triplicate with the respective standard } \\
\text { eviations. The means followed by different letters in the same column are statistically } \\
\text { ifferent }(\mathrm{p}<0.05) \text { by the Tukey test. The protein content was determined by the Kjeldahl } \\
\text { itrogen determination method using } 6.25 \text { as conversion factor. }\end{array}$} \\
\hline
\end{tabular}


Crude protein (16.48\%) and ash (5.72\%) levels of in natura heads increased to 38.41 and $19.38 \%$ in tilapia head flour, respectively, due to water elimination. It should be stressed that part of the crude protein was retained in the sieving process. These values point to tilapia head flour as an important nutritional alternative, due to its high levels of proteins and minerals, as compared to other human foods.

Total lipids found in in natura heads was $9.56 \%$, which is lower than that found by Moreira et al. (2003) for freshwater fish raised in captivity (piraputanga, matrinxã and piracanjuba), with average total lipids of $20.5 \%$. The total lipid content of the flour $(35.46 \%)$ is the highest among foods, making this flour a highly caloric product.

A total of 31 fatty acids were identified in the lipids of in natura heads and tilapia head flour (Table 2). The predominant fatty acids found were palmitic (PA, 16:0), oleic (OA, 18:1n-9), and linoleic (LA, 18:2n-6). These fatty acids were also the main fatty acids found in matrinxã, piraputanga and piracanjuba fillets by Moreira et al. (2001).

Arachidonic acid (AA, 20:4n-6), an important compound for child development, was found in quantities of $4 \mathrm{mg} .100 \mathrm{~g} \mathrm{~g}^{-1}$ in in natura tilapia heads and $16 \mathrm{mg} \cdot 100 \mathrm{~g}^{-1}$ in tilapia head flour.

Among the fatty acids of greatest nutritional importance, the $n-3$ series stands out. Alpha-linolenic acid (ALA, 18:3n-3), a precursor of other $\mathrm{n}-3$ fatty acids, was found in levels of 98 mg. $100 \mathrm{~g} \mathrm{~g}^{-1}$ and $316 \mathrm{mg} .100 \mathrm{~g} \mathrm{~g}^{-1}$ in in natura tilapia heads and in the flour, respectively. The percentages of the fatty acids EPA and DHA found in in natura heads and in the flour were $3 \mathrm{mg} .100 \mathrm{~g} \mathrm{~g}^{-1}$ and $10 \mathrm{mg} .100 \mathrm{~g}^{-1}$, and $48 \mathrm{mg} .100 \mathrm{~g}^{-1}$ and $212 \mathrm{mg} .100 \mathrm{~g}^{-1}$, respectively. The values of DHA in the flour are in accordance to those obtained by others authors (MOREIRA et al., 2003).

There were statistically significant differences among the sums of PUFA, MUFA, SFA, n-6, n-3 or the PUFA/SFA and n-6$/ \mathrm{n}-3$ ratios between the in natura heads and the flour (Table 2 ), because the total lipid content in the tilapia head flour is higher than the total lipid content in the in natura tilapia heads.

The values found for in natura head PUFA and SFA were 1,414 mg.100 g $\mathrm{g}^{-1}$ and 2,982 mg.100 g $\mathrm{g}^{-1}$, respectively. According to the British Department of Health and Social Security (DHSS, 1986), PUFA/SFA ratios lower than 0.45 are associated with unhealthy products, especially for people who suffer from cardiovascular diseases. Based on this indicator, the value of 0.47 found for the PUFA/SFA ratio in in natura heads proves the flour to be a healthy food source. Moreover, the results show that processing in natura heads into flour has no effects on the PUFA/SFA ratio. PUFA/SFA values of 1.43 were found by Turon et al. (2005) for Nile perch heads, which is higher than the values in in natura tilapia heads and flour found in the present work (Table 2).

The $n-6 / n-3$ fatty acid ratios for in natura heads and the flour were found to be 5.87 and 6.15, respectively, and showed no significant differences due to the drying process. The values found for $n-6 / n-3$ in this experiment were greater than 4.0 and were in the range from 5 to 10 , which was recommended by Simopoulos, Leaf and Salem (1999).
Table 2. Fatty acids $\left(\mathrm{mg} \cdot 100 \mathrm{~g}^{-1}\right)$ in in natura tilapia heads and in tilapia head flour (THF) ${ }^{1}$.

\begin{tabular}{|c|c|c|}
\hline Fatty acid & In natura & THF \\
\hline 14:0 & $241 \pm 12^{\mathrm{a}}$ & $829 \pm 42^{b}$ \\
\hline $14: \ln -9$ & $12.0 \pm 5^{\mathrm{a}}$ & $49 \pm 6^{\mathrm{b}}$ \\
\hline 15:0 & $8.00 \pm 1^{\mathrm{a}}$ & $68 \pm 6^{b}$ \\
\hline $16: 0$ & $1,999 \pm 43^{\mathrm{a}}$ & $7,699 \pm 35^{\mathrm{b}}$ \\
\hline $16: \ln -9$ & $60 \pm 2^{\mathrm{a}}$ & $238 \pm 6^{b}$ \\
\hline $16: 1 n-7$ & $470 \pm 7^{\mathrm{a}}$ & $1,882 \pm 101^{\mathrm{b}}$ \\
\hline $16: 1 n-5$ & $14 \pm 1^{\mathrm{a}}$ & $49 \pm 8^{\mathrm{b}}$ \\
\hline $17: 0$ & $31 \pm 3^{\mathrm{a}}$ & $111 \pm 26^{b}$ \\
\hline $17: \ln -9$ & $27 \pm 6^{\mathrm{a}}$ & $88 \pm 29^{b}$ \\
\hline 18:0 & $622 \pm 34^{\mathrm{a}}$ & $2,208 \pm 26^{\mathrm{b}}$ \\
\hline $18: \ln -9$ & $3,128 \pm 48^{\mathrm{a}}$ & $1,1447 \pm 401^{\mathrm{b}}$ \\
\hline $18: \ln -7$ & $253 \pm 37^{a}$ & $757 \mathrm{~b} \pm 52^{\mathrm{b}}$ \\
\hline $18: 1 n-5$ & $11 \pm 3^{\mathrm{a}}$ & $42 \mathrm{a} \pm 3^{\mathrm{b}}$ \\
\hline $18: 2 n-6$ (LA) & $1,018 \pm 22^{\mathrm{a}}$ & $3,784 \pm 114^{\mathrm{b}}$ \\
\hline $18: 3 n-6$ & $78 \pm 6^{\mathrm{a}}$ & $271 \pm 10^{\mathrm{b}}$ \\
\hline $18: 3 n-3$ (ALA) & $98 \pm 2^{\mathrm{a}}$ & $316 \pm 10^{\mathrm{b}}$ \\
\hline 20:0 & $18 \pm 3^{\mathrm{a}}$ & $72 \pm 6^{\mathrm{b}}$ \\
\hline $20: 1 n-9$ & $152 \pm 20^{\mathrm{a}}$ & $571 \pm 32^{\mathrm{b}}$ \\
\hline 21:0 & $27 \pm 1^{\mathrm{a}}$ & $114 \pm 10^{\mathrm{b}}$ \\
\hline $20: 2 n-6$ & $47 \pm 4^{\mathrm{a}}$ & $186 \pm 16^{\mathrm{b}}$ \\
\hline $20: 3 n-6$ & $55 \pm 3^{\mathrm{a}}$ & $215 \pm 23^{b}$ \\
\hline $20: 3 n-3$ & $10 \pm 1^{\mathrm{a}}$ & $23 b \pm 6^{b}$ \\
\hline $22: 1 n-9$ & $94 \pm 2^{\mathrm{a}}$ & $398 \pm 13^{b}$ \\
\hline $22: 2 n-6$ & $5 \pm 1^{\mathrm{a}}$ & $23 \pm 2^{\mathrm{b}}$ \\
\hline $20: 4 n-6(\mathrm{AA})$ & $4 \pm 1^{\mathrm{a}}$ & $16 \pm 2^{\mathrm{b}}$ \\
\hline $20: 5 n-3$ (EPA) & $3 \pm 1^{\mathrm{a}}$ & $10 \pm 4^{\mathrm{b}}$ \\
\hline 22:0 & $20 \pm 1^{\mathrm{a}}$ & $75 \pm 10^{\mathrm{b}}$ \\
\hline $24: 0$ & $4 \pm 1^{\mathrm{a}}$ & $13 \pm 1^{\mathrm{b}}$ \\
\hline $24: 1 n-9$ & $52 \pm 6^{\mathrm{a}}$ & $221 \pm 22^{\mathrm{b}}$ \\
\hline $22: 4 n-3$ & $47 \pm 2^{\mathrm{a}}$ & $192 \pm 22^{\mathrm{b}}$ \\
\hline $22: 6 n-3$ (DHA) & $48 \pm 2^{\mathrm{a}}$ & $212 \pm 19^{b}$ \\
\hline Not identified & $115 \pm 8^{\mathrm{a}}$ & $440 \pm 39^{b}$ \\
\hline PUFA & $1,414 \pm 60^{\mathrm{a}}$ & $5,226 \pm 133^{b}$ \\
\hline MUFA & $4,274 \pm 69^{\mathrm{a}}$ & $15,743 \pm 427^{\mathrm{b}}$ \\
\hline SFA & $2,982 \pm 60^{\mathrm{a}}$ & $11,191 \pm 68^{b}$ \\
\hline$n-6$ & $1,208 \pm 29^{\mathrm{a}}$ & $4,495 \pm 120^{\mathrm{b}}$ \\
\hline$n-3$ & $206 \pm 9^{a}$ & $731 \pm 55^{\mathrm{b}}$ \\
\hline PUFA/SFA & $0.47 \pm 0.01$ & $0.47 \pm 0.01$ \\
\hline$n-6 / n-3$ & $5.87 \pm 1.22$ & $6.15 \pm 0.50$ \\
\hline
\end{tabular}

${ }^{1}$ Each value is the average of five samples analyzed in triplicate with the respective standard deviations $(\mathrm{n}=15)$. Data were calculated using the conversion factor for fish according to Weihrauch et al., 1975. The means followedby different letters in the same line are statistically different $(p<0.05)$ by the Tukey test. Acronyms: PUFA - Polyunsaturated Fatty Acids; MUFA - Monounsaturated Fatty Acids; SFA - Saturated Fatty Acids; n-6 and n-3 fatty acids.

\section{Conclusion}

The results found lead us to conclude that processed tilapia heads in the form of flour present a high nutritive value in relation to their protein, total lipids and ash (minerals) contents. The omega- 3 fatty acid content is proved to be satisfactory by the PUFA/SFA and the $n-6 / n-3$ ratios and within the recommended levels. We thus conclude that tilapia heads can be used 
for human consumption, as a nutritive and low-cost food, adding value to a waste product that would otherwise contribute to environmental pollution.

\section{Acknowledgements}

The authors wish to thank CAPES, CNPq and Fundação Araucária for financial support.

\section{References}

ACKMAN, R. G. Fish is more than a brain food. In: International Institute for Fisheries Economics and Trade Proceedings, Quebec, 2000. p. 115-125.

BLIGH, E. G.; DYER, W. J. A rapid method of total lipid extraction and purification. Canadian Journal of Biochemistry and Physiology, v. 37, n. 18, p. 911-917, 1959.

CHARDIGNY, J. M.; BRETILLON, L.; SEBÉDIO, J. L. New insights in health effects of trans alpha-linolenic acid isomers in humans. European Journal of Lipid Science and Technology, Weinheim, v. 103, n. 7 , p. $478-482,2001$

CUNNIFF, P. A. Official methods of Analysis of AOAC international. 6. ed. Arlington: Association of Analytical Chemists. CD-Rom, 1998.

DYERBERG, J.; BANG, H. O. Homeostatic function and platelet polyunsaturated fatty acids in Eskimos. Lancet, v. 2, p. 433-435, 1979.

DHSS - Department of health and social security. (1984). Report on health and social subjects n. 28. Diet and cardiovascular Disease. London. Meat Science, Oxford, v. 42, p. 443-456, 1986.

FAO - Food and Agricultural Organization. Estatísticas da Pesca. Roma, 2000. v. 91, 141 p.

FIRBANK, E. C. et al. Eicosapentaenoic acid and docosahexaenoic acid from fish oils: differential associations with lipid responses. The Journal of Nutrition, Ilinois, v. 87, n. 5, p. 435-445, 2002.

GARCIA, D. J. Omega-3 long chain PUFA nutraceuticals. Food Technology, Chicago, v. 52, n. 1, p. 44-49, 1998.

JORY, D. E.; ALCESTE, C.; CABRERA, T. R. Mercado y comercialización de tilápia en los Estados Unidos de Norte América. Panorama Aquícola, v. 5, n. 5, p. 50-53, 2000.

JOSEPH, J. D.; ACKMAN, R. G. Capillary column gas chromatography method for analysis of encapsulated fish oil and fish oil ethyl esters: collaborative study. Journal of AOAC International, Arlington, v. 75, p.488-506, 1992.

JUSTI, K. C. et al. The influence of feed supply time on the fatty acid profile of Nile tilapia (Oreochromis niloticus) fed on a diet enriched with n-3 fatty acids. Food Chemistry, New York, v. 80, p. 489-493, 2003.

KOLANOWSKI, W.; SWIDERSKI, F.; BERGER, S. Possibilities of fish oil application for food products enrichment with omega-3 PUFA. International Journal of Food Sciences and Nutrition, Oxford, v. 50, n. 1, p. 39-49, 1999.

KOLAKOWSKA, A.; KOLAKOWSKI, E. In: Scientific Session of the Committee for Food Technology and Chemistry, PAN, Poznán, 2000. p. 14-15.
LEE, K. W.; LIP, G. H. H. The role of omega 3 fatty acid in the secondary prevention of cardiovascular disease. International Journal of Medicine, Oxford, v. 97, n. 7, p. 465-480, 2003.

MOREIRA, A. B. et al. Fatty acids profile and cholesterol contents of three Brazilian Brycon freshwater fishes. Journal of Food Composition and Analysis, San Diego, v. 14, n. 6, p. 565-574, 2001.

Composição de ácidos graxos e teor de lipídios em cabeças de peixes: Matrinxã (B. Cephalus). Piraputanga (B. Microlepis) e Piracanjuba (B. Orbignyanus) criados em diferentes ambientes. Ciência e Tecnologia de Alimentos, Campinas, v. 23, n. 2, p. 179-183, 2003.

OETTERER, M. Industrialização do pescado cultivado. 1 ed. Guaíba - RS: Editora Agropecuária, 2003.

BRASIL. Ministério da Agricultura, Pecuária e Abastecimento. RIISPOA - Regulamento da Inspeção Industrial e Sanitária de Produtos de Origem animal. Derivado do Pescado, Artigo n. 466, 1997.

PENNY, M. et al. Fish consumption. fish oil, omega-3 fatty acid and cardiovascular disease. Circulation, Arlington, v. 106, p. 2747-2757, 2002.

SCHAEFER, E. J. Lipoproteins, nutrition and heart disease. American Journal of Clinical Nutrition, Bethesda, v. 72, n. 2, p. 191-212, 2002.

SIMOPOULOS, A. P.; LEAF, A.; SALEM, N. Essentially and recommended dietary intakes for omega- 6 and omega- 3 fatty acids. Annals of Nutrition and Metabolism, New York, v. 43, n. 2, p. 127-130, 1999.

SIMOPOULOS, A. P. Omega-3 fatty acids in inflammation and autoimmune diseases. Journal of the American College of Nutrition, New York, v. 21, n. 6, p. 495-505, 2002.

STATSOFT. Statistica 5.0 software. Stasoft, Tucksa, 1995.

STRANSKY, K.; JURSIK, T.; VITEK, A. Standard equivalent chain length values of monoenic and polyenic (methylene interrupted) fatty acids. Journal of High Resolution Chromatography, Heidelberg, v. 20, p. 143-158, 1997.

THOMPSON, R. H. Simplifying fatty acid analyses in multicomponent foods with a standard set of isothermal GLC conditions coupled with ECL determinations. Journal of chromatographic science, Niles, v. 34, n. 11, p. 495-504, 1996.

TURON, F. et al. Fatty acid composition of oil extracted from Nile perch (Lates niloticus) head. Journal of Food Composition and Analysis, San Diego, v. 18, n. 7, p. 717-722, 2005.

VISENTAINER, J. V. et al. Influence of diets enriched with flaxseed oil on the $\alpha$-linolenic, eicosapentaenoic and docosahexaenoic fatty acid in Nile tilapia (Oreochromis niloticus). Food Chemistry, New York, v. 90, n. 4, p. 557-560, 2005.

WEIHRAUCH, J. L. et al. Lipid conversion factors for calculating fatty acid contents of foods. Journal of American Oil Chemists' Society, Champaign, v. 54, p. 36-40, 1977.

ZMIJEWSKI, T. et al. Salughter yield, proximate and fatty acid composition and sensory of rapfen (Aspius aspius $L$ ) with tissue of bream (Abramis brama L) and pike (Esox lucius L). Journal of Food Composition and Analysis, San Diego, v. 19, n. 2-3, p. 176-181, 2006. 